\title{
РЕСПУБЛИКА КЫРГЫЗСТАН И ВОЗВРАЩЕНИЕ РОССИИ В ЦЕНТРАЛЬНУЮ АЗИЮ
}

\begin{abstract}
Аннотация: Настоящая статья посвящена анализу иелей и задач возвращения России в Центральную Азию и роли в этом проиессе российско-кыргызского сотрудничества. Центральная Азия сегодня играет важнейшую роль в современных международных отношениях, являясь точкой пересечения интересов крупнейших мировых акторов - России, США, Китая, ЕС, и полем соприкосновения, взаимопроникновения и столкновения ценностей крупнейших мировых цивилизаций: христианства, конфуцианства и ислама. Центральная Азия на современном этапе - ключевой регион на карте мира, установление контроля над которым позволяет управлять глобальным транзитом углеводородов и других видов стратегического сырья для крупнейших развивающихся экономик и, как следствие, влиять на их экономический рост, совокупную мощь и направления экспансии. Россия сегодня возврашается в Центральную Азию в качестве ключевого внешнеполитического игрока, и в этом деле она должна опираться на давних региональных союзников и партнеров, одним из которых является Кыргызстан. Не вызывает сомнения, что сегодня России необходима выверенная под конкретные условия внешняя политика, направленная на достойное представление национальных интересов 8 регионе, поддержание стабильности у своих грании и сдерживание внешней политической, экономической и военной экспансии нерегиональных игроков, таких как США, НАТО, ЕС.

Review: This article is devoted to the goals and aims of return of Russia to the Central Asian region and the role of Russian - Kyrgyz cooperation in it. The Central Asia currently plays an important role in international relations, being the crossing point for the interests of largest global actors - Russia, the USA, China, the EU, and the field for the mutual penetration and clash of interests of largest global civilizations: Christian, Confucian and Islamic. The modern Central Asia became a key region in the global map, and control over the region allows to control global transit of hydrocarbons and other strategic raw materials for the largest developing economics, and to influence their economic growth, combined power and directions of their expansion. Russia currently is returning to the Central Asia as a key foreign political player, and it should find support in regional allies and partners, including Kyrgyzstan. There is no doubt that currently Russia needs a foreign policy, which should be adjusted to the current situation, and aimed on the support of national interests in the region, stability of the borders and restraint of the foreign political, economic and military expansion of non-regional players, such as the USA, the NATO, and the EU. Ключевые слова: Политология, Россия, Кыргызстан, Центральная Азия, внешняя политика, международные отношения, наџиональная безопасность, наџиональные интересы, интеграџия, стратегическое партнерство
\end{abstract}

Keywords: political science, Russia, Kyrgyzstan, Central Asia, foreign policy, international relations, national security, national interests, integration, strategic partnership.

последние годы Кыргызстан и Центральная Азия не являлись центральной темой в российском политическом дискурсе. Однако визиты В.В. Путина в Кыргызстан (19-20 сентября 2012 г.) и в Казахстан (4-5 октября 2012 г.) а также позиция России, озвученная Президентом РФ в концепции создания Евразийского союза, дали повод для широкой дискуссии в российском обществе. Развал СССР, приближение НАТО к границам России, прямое игнорирование интересов России практически во всех аспектах внешней политики Западной коалиции, последствия постперестроечных экономических процессов вызвали обоснованную критику идей сторонников прозападного пути развития и стали мощным импульсом возрождения альтернативного евроазиатского пути. Сегодня в Россию пришло понимание наличия необходимости сбалансированной интегра- 


\section{Национальная безопасность $4(27) \cdot 2013$}

ции с одной стороны с Евросоюзом, с другой - со странами Центральной Азии.

При рассмотрении аспектов необходимости «возвращения» России в Центральную Азию необходимо учитывать три основных аспекта, важных для России.

Военный фактор. Вывод международных коалиционных сил из Афганистана в 2014 году содержит в себе угрозу российским южным границам.

Экономический фактор. В России очень долго существовал миф о самодостаточности экономики по обеспечению полезными ископаемыми. Однако реальность показывает, что наиболее высокотехнологические отрасли страны не могут обходиться без импорта марганца, бокситов, меди, хрома, цинка, титана, олова, вольфрама, кобальта, циркония, других редкоземельных металлов и, самое важное, урана. Обеспеченность по отдельным позициям указанных ископаемых составляет менее $30 \%$. В Кыргызстане и странах Центральной Азии существуют доказанные и потенциальные месторождения редкоземельных металлов и урана.

Миграционный и цивилизационный аспекты. В странах Центральной Азии все еще проживает значительное количество русскоязычного населения, связанного с Россией совместной историей и языком. Большинство республик характеризуется относительно высокими темпами естественного прироста населения, что в сочетании с кризисным состоянием экономики усиливает проблему трудоизбыточности и воздействует на интенсивность миграционных потоков. При этом специфической чертой внешней миграции является преобладание русскоязычного населения, близкого россиянам по менталитету.

Остановимся подробнее на военных аспектах политики России в Кыргызстане. Вооруженные силы Кыргызстана были сформированы на базе частей и подразделений Среднеазиатского военного округа, дислоцированных на территории республики на момент распада СССР. При этом организационно-штатная структура соединений и частей в целом не претерпела принципиальных изменений. Вооруженные силы включают в свой состав органы политического и военного управления, соединения, части и учреждения Министерства обороны, внутренних войск Министерства внутренних дел, Государственного комитета национальной безопасности (ГКНБ), Министерства чрезвычайных ситуаций, Национальной гвардии, Службы государственной охраны, Пограничной службы и органов военной юстиции Министерства юстиции. Ядром современной кыргызской армии являются образованные в 1998 г. на основе бывшей 8-й гвардейской Панфиловской дивизии Балыкчинская, Кой-Ташская и Ошская бригады.

Комплектация личного состава всех частей и подразделений вооруженных сил производится на основе всеобщей воинской обязанности и на контрактной основе. Отток из Кыргызстана офицеров бывшей Советской армии в начале 1990-х гг. актуализировал проблему подготовки командных кадров. Для ее решения были созданы Кыргызский государственный национальный военный лицей и Бишкекское высшее военное училище (готовит офицеров по общевойсковым специальностям и технический состав для ВВС), созданное на базе бывших 5-х летных курсов МО СССР, а также на высших курсах ГКНБ национальной безопасности. В 1997 г. была открыта школа прапорщиков. Подготовка по программе офицеров запаса проводится на военных кафедрах ряда гражданских вузов.

Подготовка военных кадров осуществляется также на базах зарубежных учебных заведений на основе межправительственных соглашений с Россией, Казахстаном, США, Турцией, Германией, Китаем, Индией, Францией, Великобританией, Азербайджаном. Основная часть военных кадров обучается в России и Казахстане.

Основными направлениями российско-кыргызского сотрудничества в военной области в настоящий период являются:

- $\quad$ подготовка кадров для вооруженных сил Кыргызской Республики;

- оказание вооруженным силам Кыргызстана военно-технической помощи;

предоставление Кыргызской Республикой своей территории для дислокации российских военных объектов на условиях аренды;

- взаимодействие в области противовоздушной обороны;

- $\quad$ совместная деятельность в сфере борьбы с международным терроризмом;

- развитие производственной и научнотехнической кооперации оборонных отраслей промышленности.

На основании межправительственного Соглашения «О производственной и научно-технической кооперации предприятий оборонных отраслей промышленности», подписанного в 1994 г., в Кыргызстане по 
заказу России производятся отдельные виды продукции военного назначения. В целях координации этой деятельности в г. Бишкек с 2003 г. функционирует представительство «Рособоронэкспорта».

В рамках кооперации в военном производстве продолжается выполнение пунктов перечня мероприятий и направлений работы совместной комиссии по военно-техническому сотрудничеству, в том числе:

1. Модернизация и изготовление на ОАО Транснациональная компания (ТНК) «Дастан» бортового оборудования торпедного вооружения в интересах ВМФ России, а также в рамках планируемых поставок в третьи страны, организация сервисного обслуживания произведенной продукции.

Акционерное общество «Дастан» расположено в г. Бишкек. Является единственным в СНГ предприятием, которое еще с советских времен производит ракетоторпеды BA-111 «Шквал», а также неконтактные взрыватели, системы самонаведения и управления для ВМФ России. В частности, главный штаб ВМФ России разместил в 2008-2010 гг. на предприятии «Дастан» заказ на торпеды и оборудование, связанное с морским подводным оружием на сумму более 4 млн. долл. США.

2. Проведение модернизации, испытаний, НИОКР совместно с совместным предприятием «Озеро» и ОАО «Улан» по тематике российских предприятий, в том числе ФГУП «ЦНИИ Гидроприбор». Занимается разработкой и испытаниями новых видов торпедного вооружения. В период 1999-2000 гг. на совместном предприятии была разработана экспортная модификация торпеды «Шквал-Э».

3. Организация и проведение ОАО «Бишкекский машиностроительный завод» и ГП «Бишкекский штамповочный завод» совместно с ФГУП «ЦНИИТОЧМАШ» НИОКР по разработке новых видов боеприпасов к стрелковому оружию, а также с ОАО «КБАЛ имени Л.Н. Кошкина» - по отработке новых технологий производства патронов, централизованному изготовлению запасных частей, автоматических линий и специального измерительного инструмента.

4. Изготовление с 2002 г. на Акционерном обществе «Жанар», расположенном в г. Бишкек технических средств охраны границы, в частности радиолучевых и магнитометрических систем для сигнализационных и радиолокационных устройств. Ранее завод выпускал бортовое вычислительное оборудование для военных самолетов.
5. Для радиоэлектронной промышленности Российской Федерации продолжаются поставки комплектующих изделий, производимых кыргызскими предприятиями ОАО «Завод Айнур», ОАО «Нур», OcOО «КТЗ-Гермес».

Следует отметить, что целый ряд образцов вооружения, выпускаемого на предприятиях Кыргызстана, имеет высокий экспортный потенциал. В этой связи Москва и Бишкек прорабатывают варианты совместного производства военной продукции для экспорта в третьи страны. В первую очередь это касается выпуска военно-морского вооружения для обеспечения выполнения Россией крупных контрактов по строительству кораблей для Индии и Китая.

После распада Советского Союза Россия взяла на себя обязательства по оказанию помощи Кыргызстану в охране границы с Китаем, создании и становлении национальных пограничных войск. С этой целью 5 декабря 1992 г. были подписаны соответствующие межгосударственные договоренности о формировании на территории Кыргызстана Группы погранвойск (ГПВ) Российской Федерации в составе Ошского, Нарынского и Каракольского погранотрядов общей численностью 5 тысяч человек. Кроме охраны почти 1 тысячи км границы с Китаем, российские пограничники осуществляли пограничный контроль в международном аэропорту столицы Кыргызстана «Манас».

Во время гражданской войны в Таджикистане и активной деятельности наркокурьеров подразделения российской погрангруппы контролировали также ряд направлений на кыргызско-таджикской границе. В конце 1997 г. этот участок перешел под охрану кыргызских пограничников. Государственную границу Кыргызстана с Китаем российские пограничники охраняли до 1999 года, после чего по просьбе Бишкека передали охрану границы кыргызским пограничным частям. Практически вся материально-техническая база российской ГПВ была безвозмездно передана Кыргызстану.

После вывода российской пограничной группировки в Кыргызстане осталась только Оперативная группа пограничной службы ФСБ Российской Федерации. В соответствии с договоренностями в задачи Группы входит оказание кыргызским пограничным структурам консультативной помощи в решении организационных вопросов, связанных с техническим обеспечением, охраной границы и 
подготовкой специалистов пограничной службы. Однако уже после нескольких лет самостоятельной охраны государственной границы в политических структурах Кыргызстана стал подниматься вопрос о возможности возвращения в республику российских пограничников. Для России важно мониторить и контролировать обстановку на южных границах Кыргызстан, поскольку данный регион является ключевым ко всей оперативно-тактической обстановке Центральной Азии и позволяет контролировать не только террористические группы, но и создавать заслон наркотрафику в сторону России и Европы.

Существенным при понимании важности Кыргызстана для России является наличие Афганской гражданской войны и принципиальная неспособность и нежелание США, их союзников и их военных контингентов принести мир и согласие народу Афганистана. Наркотрафик из Афганистана стал общенациональной проблемой России (первое место по потреблению героина, потребляется $21 \%$ всего производимого героина), Евросоюза, Китая и Кыргызстана (количество наркоманов, по различным оценка составляет более 150 тыс. чел., при населении в пять миллионов человек, это очень много). По экспертным оценкам от 40 до 70\% героина поступает в Россию из Афганистана через территорию Кыргызстана. Транснациональные преступные группировки, наживающиеся на наркобизнесе и наркотрафике, стали угрозой национальной безопасности для самого Кыргызстана. А их сращивание с государственными структурами в период президентства К. Бакиева привело к существенной криминализации общества. Бюджет Кыргызстана в несколько раз меньше финансовой мощности проходящего по их территориям афганского наркотрафика.

Создание единой военной базы и продление аренды военных объектов до 2025 года в Кыргызстане является продолжением политики по развитию военной логистики. Россия, опираясь на ОДКБ и ШОС, постепенно создала и продолжает развивать комплекс механизмов и договоренностей, позволяющих надлежащим образом обеспечивать устойчивость, стабильность и безопасность в регионе. Это дает основания сформулировать сдержанно оптимистичный прогноз относительно перспектив присутствия России в Кыргызстане.

Исходя из того, что основная часть оружия и военной техники, состоящих на вооружении ВС Кыргызстана, - советского и российского производства, подавляющее большинство кыргызских офицерских кадров обучается в России, имеется основание полагать, что новое руководство Кыргызстана сохранит курс на дальнейшее укрепление взаимодействия с Россией в военной и военно-технической сферах.

В экономической сфере Россия последовательно осуществляет сотрудничество с Кыргызстаном по следующим направлениям:

1) сотрудничество в энергетической отрасли:

- $\quad$ сотрудничество по линии профильных министерств;

- реализации проекта строительства Камбаратинской ГЭС-1, ОАО «Электрические станции» и ОАО «ИНТЕР РАО ЕЭС» в рамках совместного предприятия;

- $\quad$ ОАО «ИНТЕР РАО ЕЭС», ОАО «РусГидро» и ОАО «Электрические станции» занимаются реализацией проекта по строительству первоочередных ГЭС, включая Акбулунскую, Нарынскую ГЭС-1, Нарынскую ГЭС-2, Нарынскую ГЭС-3;

- сотрудничество ОАО «Электрические станции» и ОАО «ИНТЕР РАО ЕЭС» по экспорту электроэнергии из Кыргызской Республики.

Кардинальное расширение гидроэнергетических мощностей в Кыргызстане, а также увеличение объемов экспорта электроэнергии могло бы в значительной степени облегчить решение вопросов межгосударственного энергетического обмена. Гидроэнергетический потенциал Кыргызстана огромен и даже в советское время использовался менее чем на 10\%. Поэтому гидроэнергетика Кыргызстана могла бы стать объектом широкого международного сотрудничества с привлечением помимо России, Китая и других стран (например, Индии и Пакистана);

2) сотрудничество в нефтегазовой отрасли:

- создание совместного кыргызско-российского предприятия в нефтегазовой отрасли между РАО «Газпром» и ОАО «Кыргызгаз» на базе передачи части государственного пакета акций ОАО «Кыргызгаз»;

- ОАО «Газпром» проводит работы по геологическому изучению недр на лицензионных площадях территории Кыргызской Республики;

- создание совместного предприятия с участием компаний $3 А О$ «Газпромнефть-Аэро» (Российская Федерация) и ГП ТЗК «Манас» 
(Кыргызская Республика) в целях организации авиатопливообеспечения на территории Кыргызской Республики;

3) сотрудничество в области промышленности: - развитие сотрудничества по изготовлению и поставкам предприятиям Российской Федерации оборудования, приборов автоматического контроля, узлов и деталей и комплектующих для технологического оборудования, и новых видов технологического оборудования. Данное сотрудничество может строиться на базе $\mathrm{OAO}$ «Бишкекский машиностроительный завод», ГП «Бишкекский штамповочный завод» (Министерство экономического регулирования Кыргызской Республики) и ОАО «Тульский патронный завод», ОАО «Новосибирский патронный завод», ЗАО «Барнаульский патронный завод», входящий в промышленную группу ОАО «Барнаульскийстанкостроительныйзавод», ОАО«Конструкторское бюро автоматических линий им. Л.Н. Кошкина» (Минпромторг России);

- $\quad$ создание совместного предприятия на базе ОАО «Бишкекский машиностроительный завод» по производству кремния для изготовления автономных систем электроснабжения на базе фотоэлектрических преобразователей для решения вопросов бытового освещения, отопления и пищеприготовления;

- поставка гражданской вертолетной техники типа Ка-32A11BC, Ка-226, Ми-8/17 и российской авиационной техники гражданского назначения, включая перспективные пассажирские самолеты Сухой Суперджет 100, Ан148, Ту-204CM, МС-21, а также авиатехнику специального назначения - самолет-амфибию Бе-200, беспилотные летательные комплексы. ОАО «Вертолеты России» и ОАО «Объединенная авиастроительная корпорация» (Минпромторг России);

4) сотрудничество в области сельского хозяйства: - поставка российских семян сельскохозяйственных культур для проведения сезонных полевых работ;

- гармонизация стандартов в области селекции и семеноводства сельскохозяйственных культур и сертификации семян, а также оказания содействия во взаимных поставках семенного и посадочного материала;

- $\quad$ открытие на территории Российской Федерации компаний или совместных пред- приятий по закупке в Кыргызстане сельскохозяйственной продукции, в том числе для нужд Минобороны Российской Федерации;

- у участие кыргызской стороны в тендерах Минобороны Российской Федерации по поставкам продовольствия и сельхозпродукции (фасоль).

Также имеются долгосрочные перспективы по транспортному строительству:

- $\quad$ строительство и развитие железных дорог Ашхабад-Китай, Китай-Кыргызстан-Узбекистан-Афганистан-Иран;

- строительство автомагистралей Китай-Кыргызстан-Таджикистан-Россия и КитайКыргызстан-Узбекистан-Россия, что позволит организовать единое транспортно-логистическое пространство с возможностью включения Афганистана в транспортную сеть, что будет способствовать экономическому развитию стран Центральной Азии.

Еще одним актуальным вопросом российскокыргызского сотрудничества является вопрос интеграции мигрантов на территории России и защиты русских и русскоязычных в Кыргызстане. Для России решение данных вопросов является принципиальным, поскольку законопослушные граждане Кыргызстана представляют собой наиболее естественными и благоприятными факторами исправления сложившейся негативной ситуации, а через взаимодействие с соотечественниками на территории Кыргызстана необходимо проводить собственные национальные интересы и укреплять связи двух стран в различных областях взаимодействия.

Распад СССР, либерально рыночные реформы, резкое ухудшение социально-экономической обстановки и одновременно государственного строительства Кыргызской Республики, приведшего к росту национализма - все это обеспечило существенные изменения в структуре и распределении населения по территории Кыргызстана:

1. Значительный миграционный отток русскоязычного населения привел к ухудшению качества трудовых ресурсов и снижению профессионально-квалификационный уровня значительной части населения 1 .

2. Высокая рождаемость в сельской местности еще в советское время, при отсутствии занятости на селе, вызвала неконтролируемый приток

\footnotetext{
${ }^{1}$ Regnum. - 2006. - 12 May.
} 


\section{Национальная безопасность 4(27) • 2013}

сельской молодежи в крупные города республики, что определило снижение уровня жизни городского населения и подготовило почву для люмпенизации и криминализации молодежи ${ }^{2}$.

3. Приток населения в южные районы с сопредельных территорий Узбекистана в связи с афганским конфликтом. Рост напряженности и радикальная исламизации южного направления, гражданская война в Таджикистане привели к притоку мигрантов в южные районы Кыргызской Республики ${ }^{3}$.

По экспертным оценкам, в России численность нерегулируемых трудовых мигрантов из Кыргызстане составляет до 1 млн. чел. Наиболее часто встречающаяся оценка численности трудовых мигрантов, которую высказывают различные специалисты и представители государственных органов, варьирует в пределах от 400 до 700 тыс. человек 4

Для России законопослушные граждане Кыргызстана представляют собой наиболее естественными и благоприятными факторами исправления сложившейся негативной ситуации:

1. Кризисных явлений в демографических процессах, что находит выражение в неуклонном сокращении численности населения России и его отрицательном естественном приросте (с 1955 г. по настоящее время). Эксперты предсказывают, что на фоне старения населения и усиления дефицита населения в трудоспособном возрасте Россия столкнется с усиливающейся конкуренцией за рабочую силу на мировых рынках труда, к которой она не готова.

2. На рынке труда России складывается ситуация связанная с усиливающимся дефицитом рабочих кадров для малоквалифицированных и низкооплачиваемых вакансий, когда именно трудовая иммиграция рассматривается в качестве условия заполнения ниши малоквалифицированных и низкооплачиваемых вакансий.

3. В структуре занятости коренного населения России происходят коренные изменения, про-

\footnotetext{
2 Звягельская И.Д. Становление государств Центральной Азии: Политические процессы. М.: Аспект-Пресс, 2009. С. 81-84

${ }^{3}$ Теория и идеология общественного развития / Под научн. рук. акад. Т. Койчуева. Бишкек: Илим, 2009. С. 246.

${ }^{4}$ Национальный статистический комитет Кыргызской Республики [Электронный ресурс]. - Режим доступа: http:// www.eurasianhome.org/xml/t/expert.xml?lang=ru\&nic=expert\& pid $=1458$.
}

являющиеся в неуклонном снижении доли занятых в промышленности, строительстве и на транспорте и при росте доли занятых в торговле и сфере услуг, в том числе информационных и финансовых. Структурные сдвиги в занятости привели к тому, что на рынке труда появились специфические иммигрантские ниши, которые практически невозможно заполнить за счет коренного населения.

Подводя итоги, можно констатировать, что подписанные в 2012 году соглашения о создании единой военной базы и продлении аренды являются логическим продолжением политики «возвращения» России в Кыргызстан. Широкое военное и военно-техническое сотрудничество не прекращалось и позволяет России полноценно и активно участвовать в развитии и укреплении безопасности Кыргызстана. Вывод сил США из Афганистана создаст высокий потенциал опасности для российских южных границ. Российское военное присутствие должно и дальше обеспечивать баланс сил, который позволит гарантировать безопасность и России и Республики Кыргызстан.

Прежде всего, в интересах собственной национальной безопасности для России важнейшей геополитической и дипломатической задачей в ближайшие двадцать лет является превращение территории Центральной Азии и Среднего Востока - от Казахстана до северной Индии и Персидского залива - в принципиально новый макрорегион и географический факт, отличающийся стабильностью и промышленным подъемом на основе создания единого независимого Афганистана с сильным государством и системного сотрудничества России, Индии, Китая, Ирана, Пакистана, Казахстана, Туркменистана, Таджикистана, Узбекистана, Армении, Азербайджана и Турции.

Кыргызстан, как ключевое, с точки зрения географического местоположения, государство является важным звеном в обеспечении бесперебойной логистики в военной и экономической сферах.

\section{Библиография:}

1. Годы, которые изменили Центральную Азию / Отв. ред. И.Д.Звягельская. М.: ЦСПИ, Институт востоковедения РАН, 2009.

2. Звягельская И.Д. Становление государств Центральной Азии: Политические процессы. М.: Аспект-Пресс, 2009. 
DOI: $10.7256 / 2073-8560.2013 .4 .7751$

При цитировании этой статьи сноска на doi обязательна

Внешний контур национальной безопасности

3. Звягельская И.Д. Авторитаризм в Центральной Азии: от старта и далее (какие дали он догоняет?) // Что догоняет догоняющее развитие / Отв. ред. А.М. Петров. М.: Институт востоковедения РАН, 2011.

4. Владимиров В. Политика России на южных рубежах. Поиск новой стабильности (2004-2005 гг.) // Разоружение и безопасность 2004-2005: новые подходы к международной безопасности / Под ред. А. Арбатова; Институт мировой экономики и международных отношений РАН. М.: Наука, 2007.

5. Манойло А.В. Ценностные основы управления межцивилизационными конфликтами: российская модель. // Вестник Моск. ун-та. Серия 12. Политические науки. - 2012. - №3. - С. 89-92.

6. Теория и идеология общественного развития / Под научн. рук. акад. Т. Койчуева. Бишкек: Илим, 2009.

7. Regnum. - 2006. - 12 May.

8. Национальный статистический комитет Кыргызской Республики [Электронный ресурс]. - Режим доступа: http://www.eurasianhome.org/ $\mathrm{xml} / \mathrm{t} /$ expert.xml?lang $=$ ru\&nic $=$ expert\&pid $=1458$.

\section{References (transliteration):}

1. Gody, kotorye izmenili Central'nuyu Aziyu / Otv. red. I.D.Zvyagel'skaya. M.: CSPI, Institut vostokovedeniya RAN, 2009.

2. Zvyagel'skaya I.D. Stanovlenie gosudarstv Central'noy Azii: Politicheskie processy. M.: Aspekt-Press, 2009.

3. Zvyagel'skaya I.D. Avtoritarizm v Central'noy Azii: ot starta i dalee (kakie dali on dogonyaet?) // Chto dogonyaet dogonyayuschee razvitie / Otv. red. A.M. Petrov. M.: Institut vostokovedeniya RAN, 2011.

4. Vladimirov V. Politika Rossii na yuzhnyh rubezhah. Poisk novoy stabil'nosti (2004-2005 gg.) // Razoruzhenie i bezopasnost' 2004-2005: novye podhody k mezhdunarodnoy bezopasnosti / Pod red. A. Arbatova; Institut mirovoy ekonomiki i mezhdunarodnyh otnosheniy RAN. M.: Nauka, 2007.

5. Manoylo A.V. Cennostnye osnovy upravleniya mezhcivilizacionnymi konfliktami: rossiyskaya model'. // Vestnik Mosk. un-ta. Seriya 12. Politicheskie nauki. - 2012. - №3. - S. 89-92.

6. Teoriya i ideologiya obschestvennogo razvitiya / Pod nauchn. ruk. akad. T. Koychueva. Bishkek: Ilim, 2009. 